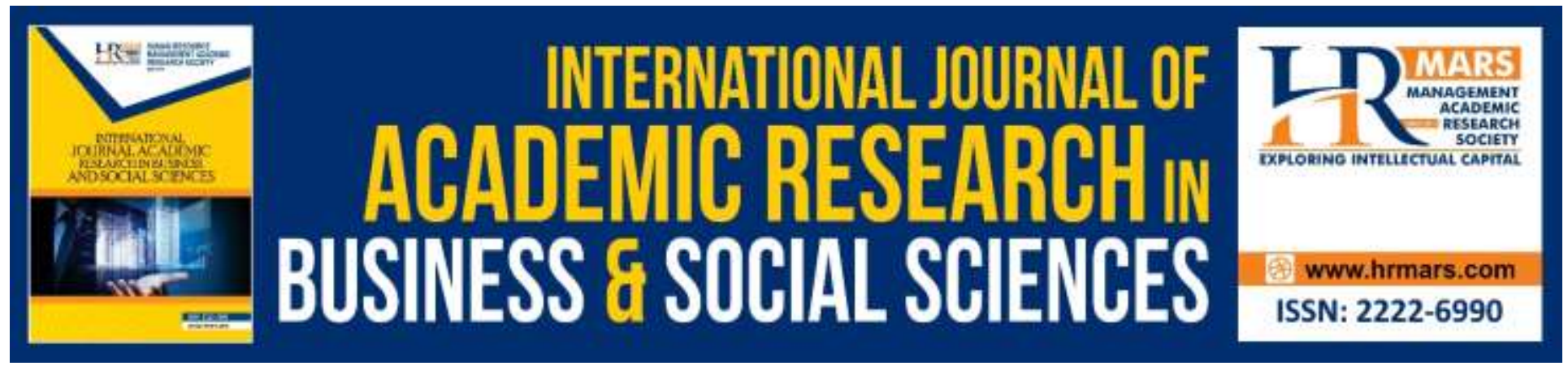

\title{
A Conceptual Framework for META ProBaca Module in Improving Reading Comprehension and Reading Fluency among Dyslexia Pupils
}

\author{
Hasliza Yunus, Noor Aini Ahmad
}

To Link this Article: http://dx.doi.org/10.6007/IJARBSS/v9-i11/6647

DOI: 10.6007/IJARBSS/v9-i11/6647

Received: 10 October 2019, Revised: 30 October 2019, Accepted: 03 November 2019

Published Online: 13 November 2019

In-Text Citation: (Yunus \& Ahmad, 2019)

To Cite this Article: Yunus, H., \& Ahmad, N. A. (2019). A Conceptual Framework for META ProBaca Module in Improving Reading Comprehension and Reading Fluency among Dyslexia Pupils. International Journal of Academic Research in Business and Social Sciences, 9(11), 1187-1200.

Copyright: (C) 2019 The Author(s)

Published by Human Resource Management Academic Research Society (www.hrmars.com)

This article is published under the Creative Commons Attribution (CC BY 4.0) license. Anyone may reproduce, distribute, translate and create derivative works of this article (for both commercial and non-commercial purposes), subject to full attribution to the original publication and authors. The full terms of this license may be seen at: http://creativecommons.org/licences/by/4.0/legalcode

Vol. 9, No. 11, 2019, Pg. 1187 - 1200

Full Terms \& Conditions of access and use can be found at http://hrmars.com/index.php/pages/detail/publication-ethics 


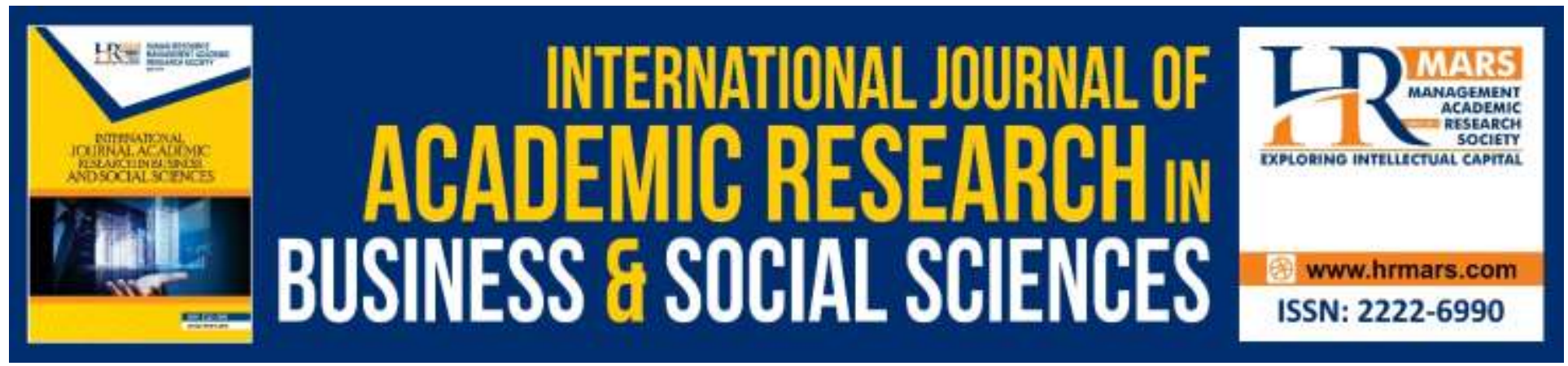

\title{
A Conceptual Framework for META ProBaca Module in Improving Reading Comprehension and Reading Fluency among Dyslexia Pupils
}

\author{
Hasliza Yunus, Noor Aini Ahmad \\ Department of Special Education, Faculty of Human Development, Sultan Idris Education \\ University, Malaysia.
}

\begin{abstract}
The limited mastery of reading skills will forestall the success of pupils not only in both the classroom and school environment but will also influence the pupil's life. Nonetheless, the ability to master reading skills is an issue for dyslexic pupils. This study designs META ProBaca module based on metacognitive theory, interactive reading model and the standard curriculum of primary education for the pupils of special need. This article examines the literature review on dyslexia, metacognitive, reading interactive, the standard curriculum of primary education for the pupils of special need, reading comprehension and reading fluency. This discussion aspires to configure the conceptual framework of the META ProBaca Module to enhance reading comprehension skills and reading fluency among dyslexic pupils in the Primary Integration Special Education Program. Predicated on the conceptual framework, the study is split into two phases namely the module development phase and module evaluation phase. In the development phase, there are one theory and two models that are adopted Flavell's metacognitive theory (1976), Interactive Reading Model (1977) and The Special National Curriculum Standard for Primary Education Curriculum (KSSRPK) Learning Problem (2017). The Four elements that are implemented in the creation of META ProBaca Module are knowledge, experience, targets and strategies. This is a homogeneous quasi-experimental type of study. The researcher splits the experimental group into two groups that are treatment and control group. The treatment group will be taught using the META ProBaca Module. The result of using the META ProBaca Module is anticipated to assist dyslexic pupils to master the skills of reading comprehension and fluency. Keywords: Reading Comprehension, Fluency Reading, Dyslexia, Module.
\end{abstract}




\section{Introduction}

The Ministry of Education (MOE) has always been firm about establishing the expansion of MBPK MP learning that can be evaluated in a more comprehensive and holistic manner. One of the eleven shifts of the Malaysian Education Blueprint 2013-2025 is to insure that every pupils master the skills in Bahasa Malaysia and English and be encouraged to learn additional languages to produce pupils who are knowledgeable, having the skill to lead, equipped with thinking skills, ethically and spiritually enabled, having a national identity, and are bilingual. (PPPM, KPM, 2018). Whilst the 108th Malaysia Education Initiative 2016-2025, the government has outlines to administer a program for teachers to establish the growth in the acquisition and competence of Bahasa Malaysia at all levels of education to uphold Bahasa Malaysia's standard.

The significance of mastering reading skills is greatly emphasized by MOE although when the pupils have disabilities. Reading skills are directly related to cognitive subcomponents (Pezzino, Breton \& Lacroix, 2019) which call for the acquisition of certain skills. There are five skills that pupils must ace in order to become a competent reader, specifically (a) phonemic awareness; (b) phonics; (c) vocabulary; (d) fluency; and (c) understanding (International Reading Panel, 2013). Reading is an intricate process concerning the interaction between the reader and the text, in which the reader will recognize the words or sentences and give meaning to the texts seen through the engagement on the certain art of the brain (Rasinski et al., 2016). The mastery of both language decoding and understanding skills is a factor in mastering reading skills (Spencer et al., 2018; Khor, Low \& Lee, 2017). Pupils with lower reading efficiency will encounter problems when they join school at secondary or higher levels which consequently hinder them to achieve great academic achievement, trigger emotional and behavioral problems, and some who even leave school (Worrell et al., 2016; Williams et al., 2016).

The ability to master reading skills is the dilemma for dyslexic pupils. Problems with dyslexic children cover some elements like both audio and visual processing weaknesses, or a combination of both which results in weakening of phonological processing (Husniza \& Zulikha, 2015). Therefore in this study, the conceptual framework of META ProBaca Module is expected to benefit dyslexic pupils to master the skills of reading comprehension and fluency. Indirectly promotes reading skills among dyslexic pupils.

\section{Literature Research}

The literature reviews to be discussed are dyslexia, metacognitive, interactive reading, The Special National Curriculum Standard for Primary Education Curriculum (KSSRPK) Learning Problem, reading comprehension and reading fluency.

\section{Dyslexia}

Dyslexia refers to the pupils who have complications in mastering the skills of reading, spelling, writing and even counting. Nevertheless, dyslexic pupils have the same ability as typical ones (Zulikha \& Husniza, 2014). Children with dyslexia have orthographic problem where it weakens 
their ability to speak verbally (Lauren et al, 2018). They will make a mistake when they want to describe the meaning of the term and the subtle or literal meaning (Cardillo et al., 2017). Dyslexia is also observed with a binocular problem by which both eyes are used simultaneously and these unstable eyes movements affect reading skills negatively (Manilla and Braga, 2017). The incapacity makes pupils with dyslexia face difficulty to master spelling skills even though this skill is the crucial factor in improving reading fluency (Ouellette, Martin-Chang and Rossi, 2017).

Dyslexic pupils use the right brain which depress their ability to think analytically and trigger problems focusing on a task (Stienen-Durand and George, 2014). As a matter of fact, dyslexic pupils's memories are limited to oral communication solely which affects the reading ability (Giorgettia \& Lorusso, 2018). The impotence of dyslexia in terms of motor coordination and the ability to understand space, affects the ability to master writing skills too (Lopez \& Campoverde, 2018). Additionally, dyslexic pupils tend to ignore the textual content when they read the text thus they do not understand the textual content of the reading and the comprehension skills are becoming harder to master (Awada \& Plana, 2018). Pupils with difficulty reading will take a long time to answer more specific questions such as differential questions, literature and background questions (Hebert et al., 2016). Therefore, the disability experienced by dyslexic pupils, particularly in neurological elements, has had a serious effect on the mastery of the components in reading skills.

\section{Metacognitive}

In the context of learning, reading involves cognitive skills such as to understand and use language or in other words, language cognitive aspects are about oral expressions, vocabulary, fluency and language comprehension while metacognition is the ability to reflect, understand and control the learning process of a pupils (Shahlan \& Saemah, 2017). Cognitive Meta refers to a high-thinking process in which one can think in process of thinking (Mohd Izwan et al., 2016). The impact of metacognitive controlling and the control of cognitive strategies have a substantial relationship (Dinsmore \& Zoellner, 2017). Having metacognitive ability in reading skills distinguishes the competent and less competent readers. Competent readers will concentrate on the meaning of the texts being read. They know reading, know why they need to read and have prepared strategies to face the problems and control information through their reading comprehension skills. Meanwhile, for the less competent readers, they have limited knowledge metacognition that make them attracted more in the process of maintaining the word rather than involve in the process of translating and understanding the meaning of the texts read (Dohra et al., 2015).

Metacognitive is valuable in all fields. Research proves too that metacognition is able to increase the level of confidence in self-sufficiency to achieve success in Mathematics among pupils with normal learning ability (Bishara \& Kaplan, 2018; Laili, 2015; Permatasari, 2016). In fact, metacognition of understanding reading skills also positively affects second language learners as well as boosting pupils' communication skills in English (Mohammad Reza et al., 2013). 
Metacognitive relations with strong Malay language achievement have made the researcher propose, so that metacognitive skills are applied in the teaching and learning process Aisyah et al., 2014. Additionally, metacognitive ownership has also shown that there are differences in adult literacy competencies that include from the aspects of linguistic, metacognitive knowledge and fluency displayed (Trapman, Gelderen, Schooten and Hulstijn, 2018).

Metacognitive strength is highlighted to every individual (Dinsmore and Zoellner, 2017). Pupilss with exceptional understanding ability suggest that they are having high metacognitive considerations. They exhibit the unbiased, charismatic characteristics and are able to handle their relationship with their friends very well (Mirandola, Ciriello, Gigli and Cornoldi, 2018). It is suggested that metacognitive aspects are applied in schools as well as at home to intensify the basics of reading comprehension skills at the very beginning (Edossa, Neuenhaus, Artelt, Lingel and Schneider, 2018). Accordingly, metacognitive aspects need to be refined in the education system, especially for special needs pupils to help them master the learned skills but also understand themselves.

\section{Reading Interactive}

Reading is a process of perception and cognitive (Wang, Silvestri \& Jahromi, 2018). Interactive reading strategies can assist pupils to think and understand better read texts. Rumelhart (1977) highlighted that reading is not a passive act, it is an active and interactive process. The Interactive Reading Model is a combination of Top-Down Reading and Bottom-up Reading. The teacher needs to understand and identify the distinction between the two reading modes when the reading model was used during teaching reading comprehension (Azar Hosseini Fatemi, Vahideh Sadat Vahedi \& Zari Sadat Seyyedrezaie, 2014).For this particular study, interactive reading concentrates on the use of technology tools to promote skills acquisition. It is even recommended that effective and comprehensive multimedia tools to help dyslexic pupilss in Malaysia can come reality by combining cultural and linguistic factors (Balamuralithara et al., 2016). The suggestion is then supported when the findings show that the use of information and communication technology is beneficial to support dyslexic pupils to understand the effective rhythm of learning (FatimaEzzahra et al., 2017).

Studies prove that there is a substantial relationship between the interactivity of the main reader and textual features for the comprehension textual understanding (Follmer \& Sperling, 2018). It is believed that pupils will be more attentive and motivated to learn when the technology element is included in the teaching and facilitating process (Thoennes, 2016). The usage of technology can improve reading skills as well as enhance individual performance and emotions in reading-related aspects too (Caute, Cruice, Marshall, Monnelly, Wilson \& Woolf, 2018). The discovery of the empirical study prove that the electronic reading programs can be adopted as a compelling learning aid and improve reading skills especially when the incompetency of pupils is unlikely to draw attention and support from parents (Horne, 2017). 
Meanwhile in India, teachers have done alternative approaches to enhance memorization mastery and continue to increase the use of phonics as a method of teaching English literacy through the application of GraphoLearn (Patel et al., 2018) and among grade one pupils literacy skills in public schools in Zambia (Folotiya et al., 2014). Thus, it is evident that technology is a critical element to be integrated in the teaching process to support other teaching approaches. The adoption of electronic tools too as a teaching aids can help stimulate pupils interaction with the learning process which results in enhancing reading skills.

\section{The Special National Curriculum Standard for Primary Education Curriculum (KSSRPK) Learning Problem}

The Special Education Curriculum aims to provide knowledge and skills through flexible teaching and learning processes to fulfill the individual needs with varying degrees of capability towards meaningful life and in line with the National Education Philosophy. The Special National Curriculum Standard for Primary Education Curriculum (Revised in 2017) is the National Curriculum accepted in all primary schools in the National Education System which as being declared accordingly with Section 18 under the Education Act 1996 [Act 550].

The special education curriculum depends on three main principles: (i) comprehensive and integrated education, which aims to focus on individual potentials comprising physical, emotional, spiritual, intellectual and social aspects; (ii) good and meaningful learning refers to the teaching and learning process that can encourage and retain the special pupils' interest in learning and (iii) Lifelong education refers to the acquisition of knowledge and skills in schooling that can encourage the development of knowledge throughout life. In order to turn the objective of (iii) into reality, then there is necessity of the pupils with special education needs to master the reading skills. The reading skills as defined in DSKP Bahasa Malaysia Standard Six refers to the ability of pupils to read with proper pronunciation, intonation, pause and fluency. Similarly, emphasis is given on the important aspects of understanding and reasoning of various materials by using various reading techniques. The mastery of reading skills can assist special needs learners to master other knowledge for the benefit of their future lives.

In this study, the researcher adopted the DSKP (Problem Learning) Revised in 2017 Bahasa Malaysia Standard Four to Six as a reference for study discussions and reading skills as the main focus of reference as a study guide in the preparation of the creation of a teaching module that will be used as an intervention to dyslexic pupils. The themes incorporated in the DSKP (Learning Problems) Revision 2017 Bahasa Malaysia Standard Four to Six will be modified and reconstructed into instruments in the module and will be used to test the level of understanding and fluency of dyslexic pupils.

\section{Reading Comprehension}

The ability to master decoding skill and language comprehension are the factors in mastering reading skills (Spencer et al., 2018; Khor, Low \& Lee, 2017). Other factors that impact the ability 
to master the reading comprehension skills are based on vocabulary, oral language, linguistic skills, memorization skills and the ability to make the difference and experience and existing knowledge that individuals possess (Capellini \& Germano, 2018). The success of reading comprehension can also be observed when readers acquire and manipulate information, and are able to use knowledge to ask questions and solve problems (Crogman, 2017).

Studies demonstrate that dyslexic children struggle in mastering words, spelling and fluency in reading accurately and correctly although dyslexic children do not exhibit intellectual disabilities and sensory sensitivities (Hulme et al., 2015). Pupils must access the texts expressed through senses and establish relationships between symbols, sounds and meanings to acquire understanding of the symbols seen. Pupils who have not yet mastered the reading comprehension in the classroom are pupilss who do not understand the text being read as it is difficult to translate questions and instructions in passages or texts (Akcamete \& Gokbulut, 2017).

Reading comprehension refers to understanding the meaning of the word, analyzing the meaning the author attempts to convey through writing and a channel to increase knowledge (Ruiz, 2015). The comprehension involved in the different reading process based on the genre of the text read (Schimmel \& Ness, 2017). Ergo, it is pointed out that pupils with disabilities to learn, need to be taught the right skills to understand reading, to allow their academic achievement to increase (Rose, 2017).

\section{Reading Fluency}

Reading fluency associates to reading comprehension (Torpa et al., 2017). Reading fluency is defined to the number of words read correctly within one minute (Borleffs et al., 2018). It is also the ability to decode text or print promptly and codify it to quick thinking (Albertini et al., 2015). Additionally, reading comprehension is regarded as an automatic indicator (Lee \& Yoon, 2015).

Efficient pupils will have extensive vocabulary, which later will help advance the level of reading comprehension. The reading fluency intervention can have a positive impact on reading comprehension (Young et al., 2017). There is a powerful relationship between the three sub skills specifically accuracy, fluency and prosody with reading fluency. Accuracy is correlated with reading comprehension. When a reader reads incorrectly, then the meaning of the text read will be misinterpreted (Khor et al., 2017). The results show that there are dissimilarities in reading fluency progress between oral reading and silent reading. The silence readability plays a significant role in the achievement of reading abilities (Ciuffo et al., 2017). Readers or pupils who are not familiar with the structure of the text and language phonetic will cause the ability to process the language of the language will be impacted which results in the level of pupils fluency as well as affecting each other (Schoenbach et al., 1999).

Reading fluency and comprehension can be attained from high-level prosody skills (Calet et al., 2017). Reading comprehension substantially indicates the reading process as well as the literacy 
curriculum especially at the secondary level (Kuhn \& Schwanenflugel, 2018). Reading credibility is particularly vital in establishing reading comprehension through cognitive ability (Yamaç \& Sezgin, 2018). Improving the level of reading fluency of pupils implies the development of pupils reading fluency holistically. (O'Connor, 2017). The results show that reading fluency interventions leaded to positive changes in oneself by helping children to see their progress (Aro et al., 2018).

\section{Conceptual Framework}

Based on the literature review, metacognitive and interactive reading can boost reading comprehension and reading fluency among dyslexic pupils in primary schools. A survey is completed to create a conceptual framework that consists of these elements in the process of synthesizing the module. There are two phases of the module development process ie Module Development Phase and Module Testing Phase.

Flavell (1979) has conferred a metacognitive model that highlights metacognitive monitoring process known as a model of cognitive monitoring as he believes that monitoring from various cognitive aspects takes place through actions and interactions between four aspects that are (a) metacognitive knowledge; (b) metacognitive experience; (c) action/strategy; and (d) assignment / goal. Previous studies have found that cognitive, metacognitive and motivational combined version strategies can assist the individual master the skills of competent reading strategies and to practice a good reading strategy that will heighten the achievement of reading comprehension (Beek et al., 2018).

The Interactive Model of Reading (Rumelhart, 1977) is a more information-seeking process for obtaining information from reference materials being read by using interactive controls. Interactive Modeling Process Reading takes place when readers use the Top-Down Reading approach to get the meaning of the text read, then shift to Bottom-up Reading to anticipate the meaning of the text.

Figure 1 presents the conceptual framework of the study. In this study, dyslexic pupils were elected as the subject of the study through purposeful sampling. The selected pupils are split into two groups namely treatment and control groups. Experimental study was completed using the ProBaca META Module. After the intervention, the subjects labeled as treatment groups are considered to have mastered the comprehension skills and reading fluency. 


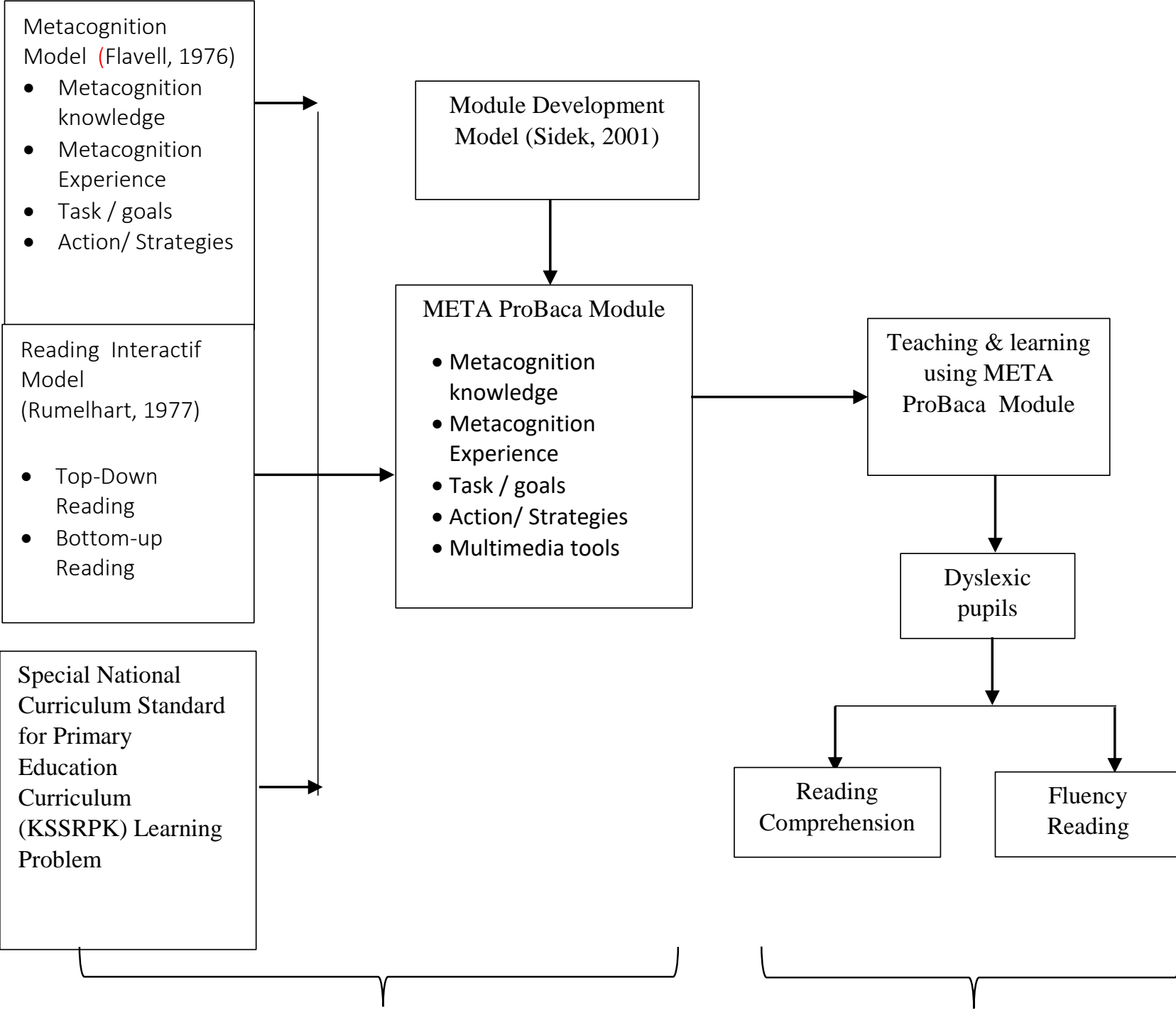

Module Development Phase
Figure 1: Conceptual Framework

Module Evaluation Phase

\section{Conclusions and Discussions}

Generally, metacognitive refers to the knowledge and application of cognitive processes that call for individuals or pupils to use, monitor and control the learning strategies adopted (Flavell, 1979). The 21st century is a digital era. The use of technology in the teaching and facilitating process will have an impact on the pupils. The incompetency to master reading skills will display psychological effects on pupil's social life (Volkmer et al., 2017). The findings of the previous study establish that the use of persuasive design software in teaching had a positive effect on academic achievement of problematic learners rather than traditional approaches (Heng et al., 2016). 
Hence, teachers need to be creative to provide teaching that is in line with the current needs of the pupils.

The researcher has designed a conceptual framework that makes metacognitive theory and interactive model of reading as the fundamental for the construction of the META ProBaca module. The META ProBaca module encompasses four basic metacognitive components: knowledge, experience, strategy and goals. An intervention will be carried out to the treatment group. After completion of the treatment given, dyslexic pupils with intervention will be able to master the reading comprehension skill and reading fluency.

\section{Corresponding Author}

Hasliza Yunus

Department of Special Education

Faculty of Human Development

Universiti Pendidikan Sultan Idris Perak Malaysia.

Email: cikguhasliza75@gmail.com

\section{References}

Akcamete, G. \& Gokbulut, O. D. (2017). Opinions of Classroom Teachers on Reading Inclusion Education and Coteaching. Springer. Qual Quant

Albertini, J. A., Marschark, M., Kincheloe, P. K. (2015). Deaf Pupils' Reading and Writing in College: Fluency, Coherence, and Comprehension. Journal of Deaf Studies and Deaf Education.

Aro, T., Viholainen, H., Koponen, T., Peura, P., Räikkönen, E., Salmi, P., Sorvo, R., Aro, M. (2018).Can reading fluency and self-efficacy of reading fluency be enhanced with an intervention targeting the sources of self-efficacy?.Learning and individual difference.

Awada, G., \& Plana, M. G. C. (2018). Multiple Strategies Approach and EFL Reading Comprehension of Learners with Dyslexia: Teacher's Perceptions. International Journal of Instruction.

Azar, H. F., Vahidah, S. V. \& Zari, S. S. (2014).The Effects of Top-down/Bottom-up Processing and Field-dependent/Field-independent Cognitive Style on Iranian EFL learners' Reading Comprehension. Theory and Practice in language Studies.

Balamuralithara, B., Hor, B. C., Zaffwan, M. I., Nizam, A. O., Fadhil, M. W. \& Azhari, M. N. A. (2016). Culturally Responsive Multimedia Tool Framework for Dyslexic Children in Malaysia: A Preliminary Study. Malaysia Journal of Society and Space.

Bishara, S., \& Kaplan, S. (2018). The Relationship of Locus of Control and Metacognitive Knowledge of Math with Math Achievements. International Journal of Disability, Development and Education.

Borleffs, E., Glatz, T. K., Daulay, D. A., Richardson, U., Zwarts, F., \& Maassen, B. A. M. (2018). GraphoGame SI:the development of a technology enhanced literacy learning tool for Standard Indonesia. Eur J Psychol Educ. 
Calet, N., Gutierrez-Palma, N. \& Defior, S. (2016). Effects of Feluency Training on Reading Vompetence in Primary School Children:The role of Prosody. Learning and Instruction.

Cardillo, R., Carcia, R. B., Mammarella, I. C. \& Cornoldi, C. (2017). Pragmatics of language and theory of mind in children with dyslexia with associated language difficulties or nonverbal learning disabilities. Applied Neuropsychology: Child.

Capellini, S. A., Germano, G. D., eds. (2018). Fluency and Reading Comprehension in Typical Readers and Dyslexics Readers. Frontiers in Psychology and Frontiers in Education.

Caute, A., Cruice, M., Marshall, J., Monnelly, K., Wilson, S., \& Woolf, C. (2018). Assistive technology approaches to reading therapy for people with acquired dyslexia, Aphasiology.

Ciuffo, M., Myers, J., Ingrassia, M., Milanese, A., Venuti, M., \& Alquino, A. (2017). How fast can we read in the mind? Developmental trajectories of silent reading fluency. Read Writ.

Crogman, H. (2017). Grasping the Interplay between the Verbal Cultural Diversity and Critical Thinking, and Their Consequences for African American Education. Frontier in Education.

Dinsmore, D. L., \& Zoellner, B. P. (2017). The relation between cognitive and metacognitive strategic processing during a science simulation. British Journal of Educational Psychology.

Dohra, F., Kok-Eng, T., \& Yunisrina, Q. Y. (2019). Investigating Metacognitive Awareness of Reading Strategies to Strengthen Pupilss' performance in Reading Comprehension. Asia Pasific Journal of Educators and Education.

Edossa, A. K., Neuenhaus, N., Artelt, C., Lingel, K., \& Schneider, W. (2018). Developmental Relationship between Declarative Metacognitive Knowledge and Reading Comprehension during Secondary School. Eur J Psychological Education.

FatimaEzzahra, B., Jamal, E. K., Ali, E., \& Sara, H. (2017). Exploring the use of the ICT in supporting dyslexic pupilss preffered learning styles: A preliminary evaluation. Educ Inf technol.

Flavell, J. H. (1979). Metacognition and cognitive monitoring: A new area of cognitivedevelopmental inquiry. American Psychologist. Muat turun daripada https://pdfs.semanticscholar.org/ee65/2f0f63ed5b0cfe0af4cb4ea76b2ecf790c8d.pdf.

Follmer, D. J., \& Sperling, R. A. (2017). Interactions between Reader and Text: Contributions of Cognitive Process, Strategy Use, and Text Cohesion to Comprehension of Expository Science Text. Learning and Individual Differences.

Folotiya, J. J., Kabali, T. C., Munachaka, J. C., Sampa, F., Yalukanda, C., Westerholm, J., Serpell, U. R. R., \& Lyytinen, H. (2014). The effect of using a mobile literacy game to improve literacy levels of grade one pupilss in Zambian schools. Education Tech Research Dev.

Giorgetti, M., \& Lorusso, M. L. (2018). Specific Conditions for a Selective Deficit in Memory for Order in Children with Dyslexia. Child Neuropsychology.

Hebert, M., Zhang X., \& Parrila, R. (2016). Examining Reading Comprehension Text and Question Answering Time Differences in University Pupils with and Without a History of Reading Difficulties. Ann. Of Dyslexia.

Horne, J. K. (2017). Reading Comprehension: A Computerized Intervention with Primary-age Poor Readers. Dyslexia .Published online in Wiley Online Library.

Hulme, C., Nash, H. M., Gooch, D., Lervåg, A. \& Snowling, M. J. (2015). The Foundations of Literacy Development in Children at Familial Risk of Dyslexia. Psychological Science. 
INTERNATIONAL JOURNAL OF ACADEMIC RESEARCH IN BUSINESS AND SOCIAL SCIENCES

Vol. 9, No. 11, November, 2019, E-ISSN: 2222-6990 @ 2019 HRMARS

Husniza, H., \& Zulikha, J. (2015). Masalah Pembacaan Kanak-Kanak Disleksia: Bagaimana Teknologi Boleh Membantu? Institut Terjemahan \& Buku Malaysia. Kuala Lumpur.

Kementerian Pendidikan Malaysia. (2016). Pelaksanaan Kurikulum Standard Sekolah Rendah (semakan 2017) Secara Berperingkat-Peringkat mulai Tahun 2017. SPI Bil 8, 2016.

Khor, C. P., Low, H. M., \& Lee I. W. (2017). Relationship between Oral Reading Fluency and Reading Comprehension among ESL Pupils. GEMA Online Journal of language Studies.

Kuhn, M. R., \& Schwanenflugel, P. J. (2018). Prosody, Pacing and Situational Fluency (or Why Fluency Matters for Older Readers). Journal of Adolescent \& Adult Literacy.

Kulesz, P. A., Francis, D. J., Barnes, M. A., \& Fletcher, J. M. (2016). The Influence of Properties of the Test and Their Interactions with Reader Characteristics on Reading Comprehension: An Explanatory Item Response Study. Journal of Education Psychology.

Laurence, P. G., Pinto, T. M., Fea, R. A. T., \& Macedo, E. C. (2018). Can a lexical decision task predict efficiency in the judgment of ambiguous sentences? Psicologia:Reflexao e Critica.

Lee, J., \& Yoon, S. Y. (2015). The Effects of Repeated Reading on Reading Fluency for Pupils with Reading Disabilities: A Meta-Analysis. Journal of Learning Disabilities.

Lopez, J., \& Campoverde. (2018). Development of Reading Comprehension with Graphic Organizers for Pupilss with Dyslexia. Journal of Technology and Science Education.

Manilla, G. T., \& Braga, J. (2017). A New Dyslexia Reading Method and Visual Correction Position Method. Global Pediatric Health.

Mercedes, S., \& Richard, K. W. (2018). The Comprehension Problems of Children with Poor Reading Comprehension despite Adequate Decoding: A Meta-Analysis. Review of Educational Research June.

Izwan, M., Sidek, M. N., Jamaludin, A., \& Marzuki, W. A. (2016). Modul Kesediaan Kerjaya Berdasarkan Teori Cognitive Information Processing (CIP). Jurnal Kurikulum \& Pengajaran Asia Pasifik.

Reza, M. A., Nizam, H. I., \& Kamarul, M. K. A. (2013). The Importance of Metacognitive Reading Strategy Awareness in Reading Comprehension. English Language Teaching. Published by Canadian Center of Science and Education.

Ng, K. H., Aryati, B., \& Azizah, A. R. (2016). Effects of persuasive designed courseware on children with learning difficulties in learning Malay language subject. Educ Inf Technol.

Nilam, P. M. (2016). Pengaruh kesadaran Metakognitif terhadap Motivassi Belajar dan kaitannya dengan Hasil belajar Metamatika Siswa Kelas XI SMA Negeri di Kota pare-Pare. AlKhwarizmi:Jurnal Pendidikan matematika dan Ilmu Pengetahuan Alam.

Nouwens, S., Groen M. A., \& Verhoeven, L. (2016). How Storage and executive funtions contribute to children's reading comprehension. Learning and Individual Differences.

Aisyah, N. M., \& Zamri, M. (2014). Tahap kemahiran Metakognitif Murid Tingkatan Empat Dalam Pembelajaran Bahasa Melayu. Jurnal Pendidikan Bahasa Melayu.

O'Connor, R. E. (2017). Reading Fluency and Pupilss With Reading Disabilities: How Fast Is Fast Enough to Promote Reading Comprehension? Journal of Learning Disabilities.

Ouellette, G., Martin-Chang S. \& Rossi M. (2017). Learning From Our Mistakes. Improvements in Spelling Lead to Gains in Reading Speed. Scientific Studies of Reading, 
Patel, P., Torppa, M., Aro, M., Richardson, U. \& Lyytinen, H. (2018). GraphoLearn India: The Effectiveness of a Computer-Assisted Reading Intervention in Supporting Struggling Readers of English Readers of English. Front. Psychol.

Pezzino, A.S., Breton, N.M. \& Lacroix, A. (2019). Acquisition of Reading and Intellectual Development Disorder. Journal of Psycholinguistic Research.

Rasinki, T. V., Rupley, W. H., Paige, D. D., \& Nichols, W. D. (2016). Alternative Text Types to Improve Reading Fluency for Competent to Struggling Readers. International Journal of Instruction.

Rose, D. R. (2017). Pupils with learning disabilities perspective on reading comprehension instruction: A Qualitative Inquiry. (Doctoral dissertation, University Trident Antarabangsa, United State Califonia) Retrieved from ProQuest Dissertations Publishing.

Ruiz, Y. (2015). Improving reading comprehension through the use of interactive reading strategies: A quantitative study (Doctoral dissertation, University of Phoenix. USA). Retrieved from http://www.proquest.com.

Rumelhart, D. E., \& McClelland, J. L. (1981). Interactive Processing Through Spreading Activation. In Lesgold, A. M. \& Perfetti, C. A., Interactive Processing in Reading. Lawrence Erlbaum Associates, Publishers Hillsdale, New Jersey.

Schimmel, N., \& Ness, M. (2017). The Effects of Oral and Silent Reading on Reading Comprehension, Reading Psychology.

Schoenbach, R., Greenleaf, C., Cziko, C., \& Hurwitz, L. (1999). What Is Reading? An Excerpt from Reading for Understanding. Download from

https://www.nwp.org/cs/public/download/nwp.../What_is_Reading_excerpt.pdf?

Shahlan, S., \& Saemah, R. (2017). Strategi Metakognitif dalam penulisan. Penerbit Universiti Kebangsaan Malaysia.

Spencer, M., Gilmour, A. F., Miller, A. C., Emerson, A. M., Saha, N. M., \& Cutting, L. E. (2018). Understanding the Influence of Text Complexity and Question Type on Reading Outcomes. Reading and Writing.

Stienen, D. S., \& George, J. (2014). Supporting Dyslexia in the Programming Classroom. Procedia Computer Science.

Thoennes, S. A. (2016). Effective Writing Interventions for Pupils with Learning Disabilities. Culminating Projects in Special Education

Torpa, M., Eklund, K., Sulkunen, S., Niemi, P., \& Ahonen, T. (2017). Why Do Boys And Girls Perform Differently On PISA Reading In Finland? The Effects of Reading Fluency, Achievement Behaviour, Leisure Reading and Homework Activity. Journal of Reading in Reading.

Trapman, M., Gelderen, A., Schooten, E., \& Hulstijn, J. (2018). Writing Proficiency Level and Writing Development of Low-Achieving Adolescents: The Roles of Linguistic Knowledge, Fluency, and Metacognitive Knowledge. Read Writ.

Laili, W. S. M. N. (2015). Hubungan Antara Perkembangan Metakognitif Dengan Pencapaian Motivasi,Sikap Belajar dan Pencapaian Matematik Dalam kalangan Pelajar Tingkatan Empat. Universiti Pendidikan Sultan Idris. Disertasi yang tidak diterbitkan. 
Wang, Y., Silvestri, J. A., \& Jahromi, L. B. (2018). Selected factors in reading comprehension for deaf and hearing adults: Phonological skills and metacognition. American Annals of the Deaf.

Williams, J. P., Kao, J. C., Poa, L. S., Ordynans, J. G., Cheng, R., \& Debonis, D. (2016). Close analysis of texts with structure (CATS): An intervention to teach reading comprehension to at-risk second graders. Journal of Educational Psychology.

Worrell, J., Duffy, M. L., Brady, M. P., Dukes, C., \& Gonzalez-DeHass, A. (2016). Training and generalization effects of a reading comprehension learning strategy on computer and paper-pencil assessments. Preventing School Failure: Alternative Education for Children and Youth.

Yamac, A. \& Sezgin Z.C. (2018). Relationships among Fourth Grades Reading Anxiety, Reading Fluency, Reading Motivation, and Reading Comprehension. Education and Science.

Young, C., Pearce, D., Gomez, J., Christensen, R., Pletcher, B., \& Fleming, K. (2017). Read Two Impress and the Neurological Impress Method: Effects on elementary pupilss' reading fluency, comprehension, and attitude. The Journal of Educational Research.

Zulikha, J., \& Husniza, H. (2014). Program Khas Integrasi Masalah Pembelajaran Spesifik: Disleksia, Dunia Sains \& Teknologi. Penerbit Universiti Putra Malaysia, Serdang. 